\title{
Quality parameters of minced meat and raw formed products on Bosnian and Herzegovinian market
}

\author{
Emina Muftić, Kenan Čaklovica², Dinaida Tahirović2, Abdullah Muftić2, Faruk Čaklovica²
}

\section{Abstract}

The aim of this research was to examine physicochemical parameters of finished and semi-finished meat products: minced meat (beef, pork and mixed meat) and raw formed meat products (ćevapi, patties/burgers and sujuk sausages), and to determine quality parameters of these products on the Bosnia and Herzegovina market. Examined parameters included: protein content, fat, collagen in meat proteins and salt $(\mathrm{NaCl})$. We analysed 282 samples of these products and found deviations with regard to the applicable Ordinance on minced meat and semi-finished and finished meat products of "The Law on Food of Bosnia and Herzegovina" in all parameters, except salt $(\mathrm{NaCl})$. The majority of deviations referred to the content of collagen in meat proteins, with as much as $21.98 \%$ of examined samples in violation of the applicable legislation.

Key words: meat quality, collagen, ćevapi, burgers, sujuk sausages

\section{Introduction}

Meat represents a significant part of human diet with highly expressed nutritive and biological characteristics. It is one of the fundamental sources of highly valuable proteins that contain balanced amino acids with high nutritive and biological value (FAO, 1992). It is important to point out that meat quality is influenced by numerous factors: type, race, fattening, anatomic region, nutrition of animals, type and size of sheds, activity of animals, age during slaughter, health of individual animals, exposure to stress before slaughter etc. (Tamba-Berehoiu et al., 2017). Above mentioned factors significantly impact the physiological composition of meat, starting from the smallest unit - cell, through muscle fibers, muscles in entirely, and in the end final product. The need for defining the quality ensues from the microstructure of meat. Skeletal muscles are consisted of several types of tissues: muscle fibers, connective and adipose tissue. Contractility, size and number of muscle fibers, as well as the composition and distribution of connective and adipose tissue play a role in preserving organoleptic characteristics, such as: color, tenderness, juiciness, flavor etc. However, biochemical and structural characteristics of muscle fibers, intramuscular connective and adipose tissues seem to play an independent role, which leads us to a conclusion that characteristics of these various muscular components can be independently modified under the influence of certain genetic or external factors, in order to improve the meat quality

${ }^{1}$ Emina Muftić, DVM, Teaching and Research Assistant, Faculty of Pharmacy, University of Sarajevo, Zmaja od Bosne 8, Sarajevo

${ }^{2}$ dr.sc. Kenan Caklovica, Assistant Professor; Abdullah Muftić, DVM, Teaching and Research Assistant, mr. sc. Dinaida Tahirović, Senior Associate; dr.sc. Faruk Caklovica, Full Professor; Veterinary faculty, University of Sarajevo, Zmaja od Bosne 90, Sarajevo

${ }^{\star}$ Corresponding author: emina.arukovic@ffsa.unsa.ba 
(Listrat et al. 2016). Since a part of meat proteins in the process of production can be substituted with some other proteins, it might influence the quality of products. Their application is legally regulated due to the protection of interests of consumers, but also due to possible harmful impact on health, since added sources of protein can cause allergic reactions (Poljanec et al., 2017). The next important component is collagen, which forms an integral part of connective tissue (McCormick, 1999). The parameter of meat quality is actually protein ratio - the content of collagen in meat proteins (collagen/protein).

Applicable legislation stipulates criteria that certain meat categories must fulfill. Those criteria primarily refer to: content of fats, proteins of meat, total proteins, proteins of connective tissue, and protein ratio of collagen/proteins of meat. Apart from the mentioned, it is important to note that salt $(\mathrm{NaCl})$ plays an important role in texture and composition of meat, since it impacts the solubility of microfiber proteins (actin and myosin) and it has an influence on protein capacity of retaining of water. When salt is added to meat and proteins are dissolved, meat viscosity reduces. When the quantity of salt is reduced, the reduction of quantity of extracted and dissolved proteins occurs, which reflects on the composition and meat quality (Barat and Toldra, 2011). Regarding food of animal origin the main emphasis is on food safety and hygiene, meeting the microbiological criteria in accordance with the applicable regulations. However, the quality of those products of animal origin was probably considered less relevant for consumers until several years ago. Regulation on minced meat, semi-finished and finished meat products (No. 82/13), hereinafter referred to as the Regulation, stipulates the requirements for ground meat, products and semi-products of meat, both in production and in the market.

The aim of this study was to examine quality parameters of minced meat and raw formed products (such as ćevapi , burgers/patties, sausages and related products) on the Bosnian and Herzegovinian market. Obtained data were compared with reference values, defined under the Regulation on minced meat, semi-finished and finished meat products.

\section{Materialandmethods}

The examination of physicochemical parameters was performed on three types (beef, pork and mixed) of minced meat and three types of raw formed products (ćevapi, burgers/patties and sausages), products of beef and mixed meat. The samples were collected from retail shops (butcher shops) in the following cantons: Sarajevo, Zenica - Doboj, Tuzla, Herzegovina - Neretva, Una - Sana Canton and Central Bosnia Canton. A total 282 samples (Table 1 ) were analyzed and the samples were submitted in individual quantity of $300 \mathrm{~g}$ and examined on the same day upon sampling. Analyses were conducted in the Laboratory for control of chemical and biological residues and quality control of foodstuffs of animal origin at the Veterinary Faculty in Sarajevo.

Fat content was determined according to the method ISO 1443:2007.

Content of hydroxyproline was determined according to the method ISO 3496:2007. Hydroxyproline content was measured on a spectrophotometer at a wavelength of $558 \mathrm{~nm}$. Collagen content was calculated by multiplying hydroxyproline by a factor of 8 .

Determination of total protein content was performed according to ISO 937: 2007. Namely, this method first obtains the nitrogen content from the sample, which is subsequently multiplied by the factor for the sample type, then the total protein content obtained. Total connective tissue content was obtained by calculating the ratio of collagen protein content multiplied by 100 .

The determination of salt $(\mathrm{NaCl})$ was performed by the Mohr method - silver nitrate titration.

The SPSS version 21.0 software was used for statistical data analysis, and we used the Chi-square test for all calculations.

\section{Resullsand disculssion}

Anex IV of Regulation on minced meat, raw semi-finished and finished meat products of "Bosnian and Herzegovinian Food Law" states requirements for minced meat (Table 1.).

Since we examined minced beef, minced mixed meat, minced pork meat, beef ćevapi, mixed ćevapi, sausages and patties/burgers, parameters of reference values are defined by the Regulation (Table 2.).

Table 3. shows analysis results of samples, where red colored numbers are numbers of samples that were not in accordance with Regulation. Total of 282 samples were analyzed. Chart 1 shows that 
Table 1 Anex IV of Regulation on minced meat, raw semi-finished and finished meat products

\begin{tabular}{|c|c|c|}
\hline \multicolumn{1}{|c|}{ Fat content } & Conective tisue: meat protein ratio \\
\hline Lean minced meat & $\leq 7 \%$ & $\leq 12 \%$ \\
\hline Minced pure beef & $\leq 20 \%$ & $\leq 15 \%$ \\
\hline Minced meat containing pigmeat & $\leq 30 \%$ & $\leq 18 \%$ \\
\hline Minced meat of other species & $\leq 25 \%$ & $\leq 15 \%$ \\
\hline
\end{tabular}

Table 2 Reference values according to Regulation on minced meat, raw semi-finished and finished meat products

\begin{tabular}{|c|c|c|c|c|}
\hline & Fat (\%) & Protein (\%) & Collagen/protein (\%) & NaCl (\%) \\
\hline Minced beef meat & Max 20 & Min 18 & Max 10 & NP $^{*}$ \\
\hline Beef ćevapi/patties & Max 25 & Min 14 16 & NP \\
\hline Beef sausages & Max 25 & Min 14 & Max 16 & $<1$ \\
\hline Minced mixed meat & Max 30 & Min 18 & Max 10 & NP \\
\hline Mixed ćevapi & Max 30 & Min 14 & Max 16 & $<1$ \\
\hline Minced pork meat & Max 25 & Min 18 & Max 10 & $<$ \\
\hline
\end{tabular}

$N P^{*}$ - not specified in the Regulation

Table 3 Results of the quality parameters of examined samples

\begin{tabular}{|c|c|c|c|c|c|c|c|c|c|c|c|c|}
\hline \multirow{2}{*}{$\begin{array}{l}\text { Types of } \\
\text { samples }\end{array}$} & \multirow{2}{*}{$\begin{array}{c}\text { Number } \\
\text { of } \\
\text { samples }\end{array}$} & \multicolumn{3}{|c|}{$\begin{array}{c}\text { Proteins } \\
\text { number of samples }\end{array}$} & \multicolumn{3}{|c|}{$\begin{array}{l}\text { Collagen/protein } \\
\text { number of samples }\end{array}$} & \multicolumn{3}{|c|}{$\begin{array}{c}\text { Fat } \\
\text { Number of samples }\end{array}$} & \multicolumn{2}{|c|}{$\begin{array}{c}\mathrm{NaCl} \\
\text { number of } \\
\text { samples }\end{array}$} \\
\hline & & $<14 \%$ & $14-18 \%$ & $>18 \%$ & $\leq 10 \%$ & $\begin{array}{c}10,01- \\
16 \%\end{array}$ & $\begin{array}{c}>16,01 \\
\%\end{array}$ & $\leq 25 \%$ & $\begin{array}{c}25,01- \\
30 \%\end{array}$ & $\begin{array}{c}>30,01 \\
\%\end{array}$ & $<1 \%$ & $>1 \%$ \\
\hline $\begin{array}{c}\text { Beef } \\
\text { minced } \\
\text { meat }\end{array}$ & 62 & 0 & 5 & 57 & 37 & 24 & 1 & 60 & 2 & 0 & 62 & 0 \\
\hline $\begin{array}{c}\text { Mixed } \\
\text { minced } \\
\text { meat }\end{array}$ & 11 & 0 & 0 & 11 & 10 & 1 & 0 & 11 & 0 & 0 & 11 & 0 \\
\hline $\begin{array}{c}\text { Pork } \\
\text { minced } \\
\text { meat }\end{array}$ & 15 & 0 & 1 & 14 & 14 & 1 & 0 & 15 & 0 & 0 & 15 & 0 \\
\hline Beef ćevapi & 62 & 0 & 26 & 36 & 15 & 32 & 15 & 58 & 3 & 1 & & \\
\hline $\begin{array}{l}\text { Mixed } \\
\text { ćevapi }\end{array}$ & 6 & 0 & 3 & 3 & 4 & 2 & 0 & 5 & 1 & 0 & & \\
\hline $\begin{array}{c}\text { Beef } \\
\text { sausages }\end{array}$ & 62 & 2 & 23 & 37 & 18 & 32 & 12 & 57 & 4 & 1 & & \\
\hline $\begin{array}{l}\text { Beef pat- } \\
\text { ties/burgers }\end{array}$ & 64 & 0 & 27 & 37 & 20 & 27 & 7 & 59 & 5 & 0 & & \\
\hline
\end{tabular}

minced beef deviates most from the legal norms specified for collagen content in meat proteins, since as many as 25 samples did not comply with the standards ( $40.32 \%$ of the 62 samples tested) and there is no statistically significant difference between the number of samples within the reference and outside the reference values $(\mathrm{P}=0.128)$. Total of the 62 samples of beef ćevapi were tested and $15(24.19 \%)$ of them did not comply with Regulation. Results of beef sausages analysis showed 19.32 $\%$ unsatisfactory samples and the results of analyz- es of beef patties/burgers showed $10.93 \%$ of unsatisfactory samples. There were statistically significant differences between samples inside and outside the reference values $(P=0.000)$ for beef ćevapi and patties/burgers. One result of minced pork meat was unsatisfactory, out of a total of 15 tested, as well as one unsatisfactory minced mixed meat result of 11 tested, while mixed ćevapi showed satisfactory results of collagen content parameter in meat proteins. Comparison between meat types is shown in Table 4. Based on the statistical analysis using the 


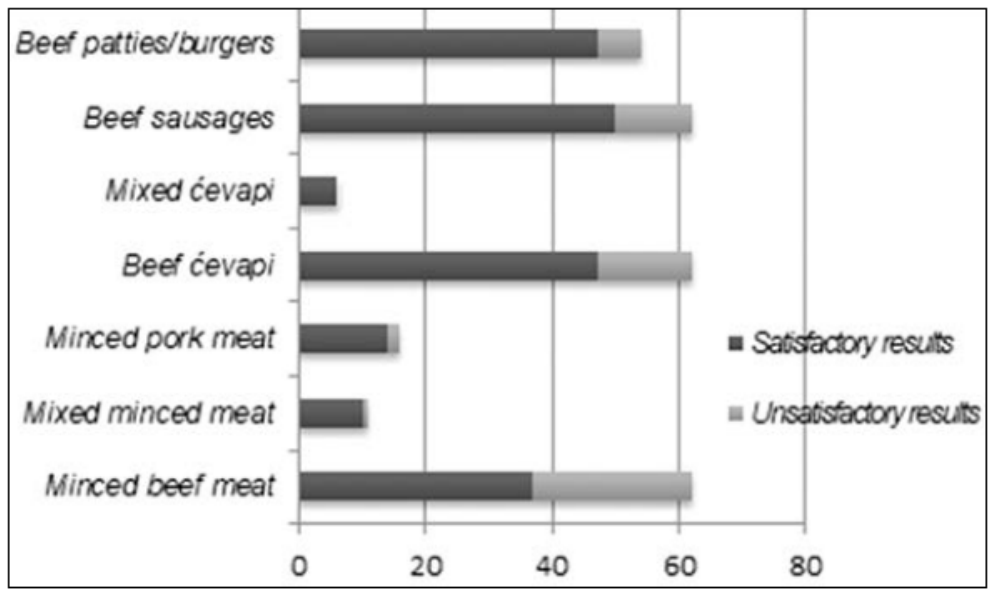

Chart 1. - Results for the collagen/protein parameter in relation to the Regulation on minced meat, semi-finished and finished meat products (No. 82/13)

chi-square test, we concluded that there is a statistically significant difference between the sample type and the determined parameter, which can be deduced from the table. There is a statistically significant difference for fat, protein and collagen/protein parameters regarding the sample types, and the $\mathrm{P}$ value is shown in Table 4.

The quantity of collagen in proteins of meat offers the highest deviations in relation to the values stipulated by the Regulation, where $21.98 \%$

Table 4 Comparison of results between types of samples

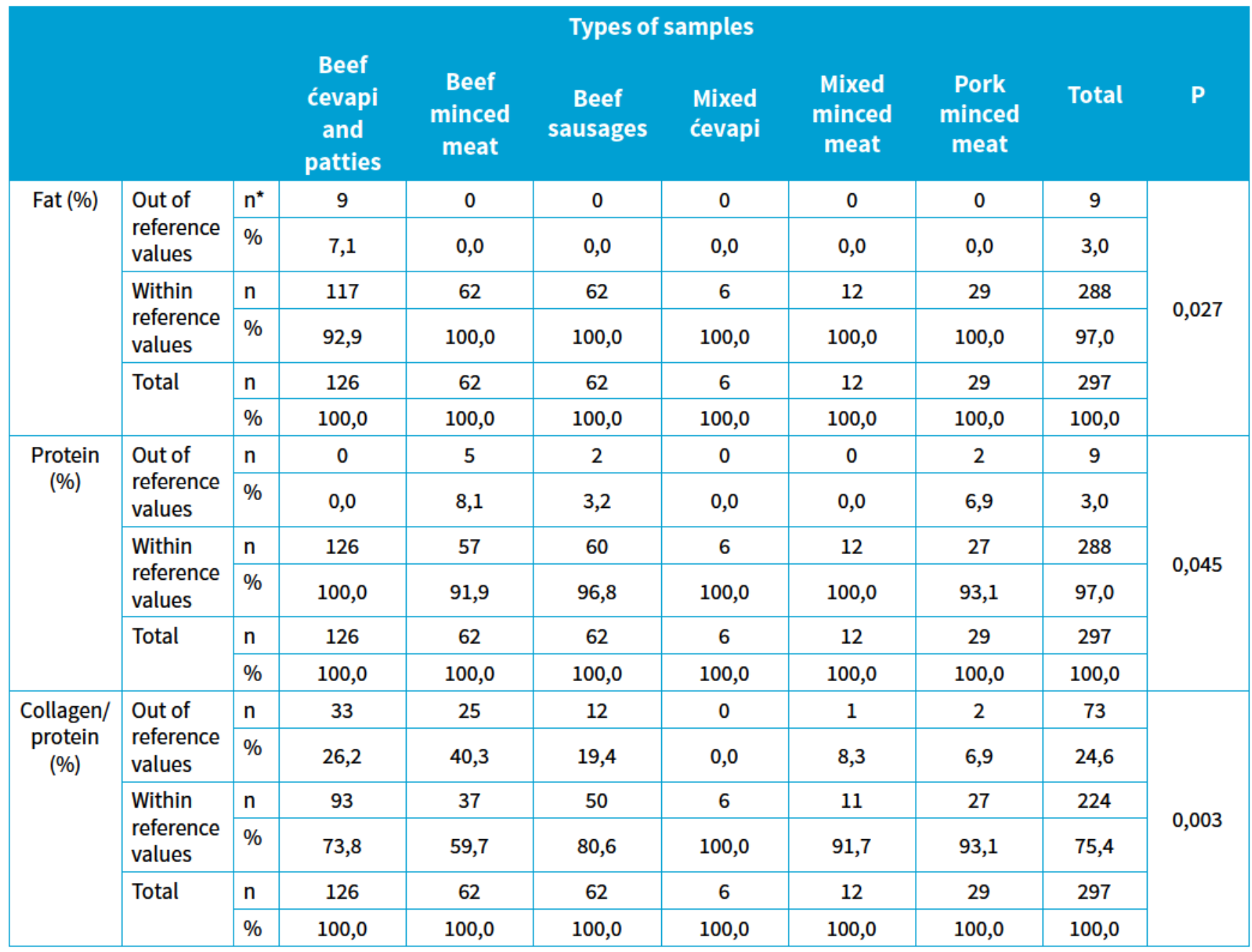


of samples were not in accordance with the Regulation (62 samples out of total 282 examined). Furthermore, $3.19 \%$ (9 samples out of total 282) samples had unsatisfactory results of fat content, and $2.83 \%$ (8 samples out of total 282) of examined samples did not have results in accordance with values of proteins that are stipulated by the Regulation. Kozačinski et al (2017) examined the basic chemical composition of burgers (lamb, beef, lamb: beef $=50: 50 \%$, lamb: beef $=75: 25 \%$ ) where the average content of fat in beef burgers totaled $4.62 \%$, and average content of proteins is $20.08 \%$. In our research, the average quantity of fat for 64 samples of beef burgers totaled $13.0 \%$, while the average content of proteins totaled $18.8 \%$. This leads us to a conclusion that samples of beef burgers in the market of Bosnia and Herzegovina contain larger quantity of fat and less content of proteins in relation to beef burgers examined in the Republic of Croatia. Ljutić et al. (2019) obtained similar results during their research on minced meat in the city of Zagreb, where $21 \%$ of total number of samples was not in accordance with values that are stipulated by the applicable legislation in Republic of Croatia. Polak et al. (2018) examined the influence of technological procedures on physicochemical characteristics of beef burgers (which are included in the category of raw formed products) where they obtained values of content from $21.33 \%$ to $22.36 \%$ (depending on technological phase), then the values of content of fat totaled from $10.05 \%$ to $14.14 \%$ (also depending on technological phase). Regarding the impact of collagen quantity on meat quality, we would like to refer to research (Rogov et al., 1992) that was conducted through biological experiment with the aim of determining specific changes in biological value of minced meat followed by increase of protein ratio of collagen/proteins $6.1 \%$ to $21.2 \%$. In the mentioned experiment, variations were detected in the quantity of proteins that the animals consumed. The quantity of protein intake through meat was falling down commensurate to the increase of content of collagen in the total protein. Values of PER (protein efficiency ratio) and NPU (net protein utilization) were also changing depending on the proportion of collagen in meat meal, with noticeably smaller biological usability and value of proteins in the presence of larger quantity of proteins of connective tissue (collagen). When this level of collagen is properly distributed and meat is thermally processed, the usability of both essential and non-essential amino acids is optimal. Usability of proteins for biosynthe- sis is increased, consequently increasing their biological value, too. Every further increase of this ratio will result in decrease of the mentioned parameters (Rogov et al., 1992). In other conducted researches it was also presented that it is inversely proportionate dependence of effect of collagen on biological value of meat (Reutersward et al., 1985).

New legal regulations stipulate the obligation of more transparent informing through more detailed mentioning of necessary information (defined by Regulation) at the declaration. We would like to point out that the Regulation, inter alia, discusses in detail and it provides parameters of quality of these types of meat and meat products. Furthermore, it defines manufacturer's specification and its elements, with the help of which the consumers have exact insight into the origin or raw material, composition of products, demands of quality etc. The results of this research paper, apart from the mentioned, may indicate the need of correct declaration of category (I and II) of minced meat. In samples of beef minced meat, mixed minced meat and pork minced meat were examined the following parameters: the content of fat, proteins, protein ratio collagen/protein and salt ( $\mathrm{NaCl})$. In samples of beef ćevapi, mixed ćevapi, beef sausages and beef burgers were examined the parameters of: content of fat, proteins, and protein ratio collagen/meat.

\section{Conclusion}

Based on results of our research, it can be concluded that ratio of collagen/protein, as a parameter of quality of minced meat and meat products, had significant deviations in relation to values stipulated by the applicable legislation in Bosnia and Herzegovina. Manufactures of food of animal origin are obliged to declare properly these products with the aim of achieving transparency regarding the composition of the mentioned products, which will also define their quality. In addition, making proper declarations is necessary in the segment of consumer protection, so that they could bring better and safer decisions in case of procurement of products of animal origin. Since samples come from almost entire territory of Bosnia and Herzegovina, it is necessary to increase controls and undertake measures of constant supervision with the aim of protection of both consumers and manufacturers. 


\section{References}

[1] Barat, J.M., F. Toldra (2011): Reducing salts in processed meat products. In J.P. Kerry and J.F. Kerry (Eds), Processed meats: Improving Safety, Nutrition and Quality, Woodhead Publishing Ltd., Cambrige, pp. 331-345.

[2] FAO (1992): Chapter 3 - Meat and health of Meat and meat products in human nutrition in developing countries by Arnold Bender. URL: http://www.fao.org/docrep/t0562e/t0562e05.htm (19.02.2020.)

[3] ISO 1443:2007 (2007): Meat and meat products - Determination of total fat content.

[4] ISO 3496:2007 (2007): Meat and meat products - Determination of hydroxyproline content.

[5] ISO 937:2007 (2007): Meat and meat products - Determination of nitrogen content (Reference method).

[6] Kozačinski, L., M. Simpraga, A. Shek Vugrovečki, B. Njari, Ž. Cvrtila (2017): Kvaliteta mesnih pripravaka od janjećeg mesa. Meso 19 (6), 508-512.

[7] Listrat, A., B. Lebret, I. Louveau, T. Astruc, M. Bonnet, L. Lefaucheur, B. Picard, J., Bugeon (2016): How muscle structure and composition influence meat and flesh quality. The Scientific World Journal, 1-14.

[8] Ljutić, D., M. Malenica, G. Krešić, T. Lešić, S. Kolarić Kravar, L. Dergestin Bačun, J. Pleadin (2019): Kvaliteta mljevenog mesa s područja grada Zagreba. Meso XXI (6), 586-593.

[9] McCormick, R.J. (1999): Extracellular modifications to muscle collagen: Implications for meat quality; Poultry Science 78, 785791.

[10] Polak, T., M. Lušnic Polak, G. Sok, L. Demšar (2018): The effect of technological procedure of making burgers on their physico-chemical parameters and sensory properties. Meso XX (2), 122-128.

[11] Poljanec, I., N. Vahčić, G. Krešić, S. Kolarić Kravar, N. Kudumija, J. Pleadin (2017): Alergeni u mesnim proizvodima s hrvatskog tržišta. Casopis Meso, XIX (5), pp. 426-433.

[12] Reutersward A.L., N.G. Asp, I. Bjorck (1985): Protein digestibility of pigskin and bovine tendon in rats; International Journal of Food Science \& Technology, 20, 6, 745-752.

[13] Rogov, I.A., E.S. Tokaev, Y.I. Kovalev, V.B. Tolstoguzov (1992): Collagen and its rational content in meat products: Part 1. Analytical studies, Meat Science, 31, 1, 35-42.

[14] Regulation on minced meat, semi-finished and finished meat products (No. 82/13) / Pravilnik o ustinjenom mesu, poluproizvodima i proizvodima od mesa (2013). Službeni glasnik Bosne i Hercegovine broj: 82/13.

[15] Tamba-Berehoiu, R.M., L. Vişan, M. Turtoi, V. Simion , C.N. Popa (2017): Qualitative aspects concerning certain minced meat products from romanian market. Scientific Papers Series Management, Economic Engineering in Agriculture and Rural Development, 17,(1), 447-452.

\section{Parametri kvalitete mjjevenong mesa i siriovih oblikovanih proizuoda na bosansko-hercegovaǎkom tř̌̌štu}

\section{Sažetak}

Cilj istraživanja je bio ispitati fizikalno-kemijske parametre proizvoda i poluproizvoda od sirovog mesa: mljeveno meso (juneće, svinjsko i miješano) i sirovi oblikovani proizvodi (ćevapi, pljeskavice i sudžukice) i parametre kvalitete ovih proizvoda na bosansko-hercegovačkom tržištu. Ispitivani parametri su: sadržaj proteina, masti, kolagena u proteinima mesa i soli $(\mathrm{NaCl})$. Ispitana su 282 uzorka navedenih proizvoda, te su utvrđena odstupanja u svim parametrima, izuzev soli (NaCl), u odnosu na važeći Pravilnik o usitnjenom mesu, poluproizvodima i proizvodima mesa. Najviše odstupanja je bilo u sadržaju kolagena u proteinima mesa, gdje čak $21,98 \%$ ispitanih uzoraka nije bilo u skladu sa normativima.

Ključne riječi: kvaliteta mesa, kolagen, ćevapi, pljeskavice, sudžukice



\section{Zusammenfassung}

Ziel dieser Untersuchung war es, die physikalisch-chemischen Parameter von fertigen und halb- 
fertigen Fleischprodukten: Hackfleisch (Rind-, Schweine- und Mischfleisch) und roh geformte Fleischprodukte (Ćevapi, Burger und Würste) sowie die Qualitätsparameter dieser Produkte auf dem bosnischen und herzegowinischen Markt zu untersuchen. Es wurden folgende Parameter untersucht: Gehalt an Proteinen, Fett, Kollagen in Fleischproteinen und Salz $(\mathrm{NaCl})$. Es wurden 282 Proben dieser Produkte analysiert. Bei allen Parametern, mit Ausnahme von Salz ( $\mathrm{NaCl})$, wurden in Bezug auf die gültige Verordnung über Hackfleisch und halbfertige und fertige Fleischprodukte Abweichungen festgestellt. Die Ergebnisse dieser Untersuchungen zeigten die meisten Abweichungen beim Kollagengehalt in Fleischproteinen; dabei entsprach sogar 21,98 \% der untersuchten Proben nicht der gültigen Gesetzgebung.

Schlüsselwörter: Fleischqualität, Kollagen, Ćevapi, Burger, Würste

\section{Los parámetros de calidad de carne picada y de los productos formados cruddos en el mercadodo de Bosnia y Herzegovina}

Resumen

El objetivo de este trabajo fue examinar los parámetros fisicoquímicos de los productos cárnicos y de los productos semiacabados de carne cruda: la carne picada (carne de res, de cerdo y carne mixta) y de los productos cárnicos formados crudos (ćevapi, hamburguesas y salchichas) y los parámetros de calidad de estos productos en el mercado de Bosnia y Herzegovina. Los parámetros examinados son: el contenido de proteínas, las grasas, el colágeno en las proteínas de carne y la sal ( $\mathrm{NaCl}$ ). Fueron analizadas 282 muestras de los productos mencionados y hubo desviaciones en todos los parámetros, excepto la sal ( $\mathrm{NaCl}$ ), en relación con el Reglamento vigente sobre la carne picada, los productos cárnicos semiacabados y los productos cárnicos. La mayoría de las desviaciones fue en el contenido del colágeno en las proteínas de carne, donde hasta $21,98 \%$ de las muestras fueron incompatibles con la regulación normativa.

Palabras claves: calidad de carne, colágeno, ćevapi, hamburguesas, salchichas

\section{Parametri qualitativi della carne macinata e dei prodotti di carne macinata cruda sul mercato bosniaco-erzegovese}

\section{Ríassunto}

Lo scopo della ricerca consisteva nell'esaminare i parametri fisico-chimici dei prodotti finiti e dei semilavorati di carne cruda: carne macinata (di bovino, suino e mista) e prodotti di carne macinata cruda (ćevapi, pljeskavice e sudžukice), oltre ai parametri qualitativi di questi prodotti sul mercato bosniaco-erzegovese. La ricerca ha esaminato i seguenti parametri: contenuto di proteine, di grassi, di collagene nelle proteine della carne e di sale $(\mathrm{NaCl})$. Nei 282 campioni analizzati sono stati accertati scostamenti in tutti i parametri esaminati, ad eccezione del sale $(\mathrm{NaCl})$, rispetto al vigente Regolamento sulla carne macinata, i semilavorati e i prodotti a base di carne. I maggiori scostamenti sono stati riscontrati in ordine al contenuto di collagene nelle proteine della carne, dove ben il $21,98 \%$ dei campioni esaminati è risultato non a norma.

Parole chiave: qualità della carne, collagene, ćevapi, pljeskavice, sudžukice 